ISBN 978-93-84468-86-6

2016 International Research Conference on Social Sciences, Humanities and Interdisciplinary Studies

(RCSSHIS-2016)

Pattaya (Thailand) Dec. 16-17, 2016

\title{
Shafi School of Thought: An Analytic Study of its Revival
}

\author{
Dr. P.S. Syed Masood Jamali \\ Professor \& Dean, \\ School of Islamic Studies, B.S. Abdur Rahman University, Vandalur, Chennai, India. \\ Email : dean-sis@bsauniv.ac.in
}

\begin{abstract}
In the history of Islamic Jurisprudence, Imam Shafi occupies an important position in terms of his unique contribution to the field. In the second century of Hijrah, two principal schools of thought emerged. One was the School of Iraq of which jurists exercised liberal analogy and its forerunner was Imam Abu Haneefa. The other was the School of Hijaz of which Jurists, upholding the prophetic tradition, rejected free analogy and its forerunner was Imam Malik. In the next generation, Imam Shafi, who graduated under the School of Malik, an offshoot of school of Hijaz, was continuously defending the Maliki School and advocating for the supremacy of the Prophetic Tradition. However, in the later stage, he introduced his own school in Bagdad between 190 AH and 199 AH by teaching and authoring his books Al Risalah and Al Umm. Further, when he migrated and settled in Egypt he comprehensively modified and established his new school of thought (Madhab). Thus, Shafi School has two phases: old and new.

Why Imam Shafi, the disciple of Malik introduced his own School at Bagdad and revived it within a short period at Egypt? How far the environmental factor of Egypt caused for transforming the old school of Bagdad into new school of Egypt? Was the Shafi school projected a balance between Hanafi and Maliki schools? To find answer to these questions, this paper discusses about the unique aspects of Shafi School and the different atmosphere where it was evolved. It also examines the principles and methodology that adopted and their impact on his old and new school of thought.
\end{abstract}

Keywords: Free analogy, Al Risala, Al Umm, school of Shafi

\section{Introduction}

Imam Shafi who was born in $150 \mathrm{AH}$ at Gaza, a town in Palestine had arrived Makkah at the age of ten along with his mother. ${ }^{[1]}$ His father who belonged to the tribe of Quraish died when Shafi was an infant. ${ }^{[2]}$ In spite his high family status as Quraish, the young orphan Muhammed Bin Idris Al Shafi grew up in poverty. In Makkah, the hometown of his ancestors, the young Shafi devoted to learning with keen interest. He learned the Prophetic Traditions and Islamic Jurisprudence under many Jurists particularly Muslim Bin Khalid Al Zanji, Mufthi of Makkah, Sufyan Bin Uyayna and others. ${ }^{[3]}$

In order to develop his language skill, Shafi lived in villages near by Makkah for a certain period with a most eloquent Arab tribal community Al Hudhail, where he learned classical Arabic poems and natural village life style. He returned to Makkah equipped himself with eloquent Arabic language style. ${ }^{[4]}$

Shafi was gifted with a sharp intelligence and a good memory. He memorized the Holy Quran at the age of seven and Malik's Al Muwatta at the age of ten. Recognizing his mastery over jurisprudence, he was declared qualified to practice law and issue fatwa at the age of fifteen by his master Al Zanji. However, Shafi desired to expand the scope of his learning by seeking admission in the school of Medina under Imam Malik, the leading jurist of Hijaz. 


\section{Upholding the Sunnah and defending the School of Malik}

At his first appearance, the young Shafi was able to impress the master and became one of the special students of Malik. On many occasions the master admired of Shafi's intelligence and eloquent expressions. During nine year stay, till the death of Imam Malik in $179 \mathrm{AH}$, Shafi had acquainted with thorough knowledge of Hadeeth and Fiqh and was able to lead the school of Hijaz after his master. Shafi came out of Madinah as a true follower of Malik defending the school of Hijaz.

Due to poverty, Shafi joined the state service in Yemen in $179 \mathrm{AH} .^{[5]}$ Though he proved to be a good jurist and administrator, he was dismissed from his service and deported to the court of Khalifa Haroon Rasheed in Bagdad on the allegation that he supported the group of Shi'a against Abbasids dynasty.

In the court, Shafi was able to impress Haroon Rasheed by his eloquent speech. Imam Mohammed Al Shaybani, the famous Hanafi Jurist who was present at the court had also witnessed that Shafi was a learned person and would not be an accused. As a result, Haroon Rasheed patronized Shafi and Al Shaybani had taken him under his guardianship. Staying with Al Shaybani at Bagdad in the circle of Hanafi Jurists, Shafi, the true student of Imam Malik and the follower of School of Hijaz, had exposed to new experiences and different arguments of Iraqi Jurists.

At the same time, Shafi studied Hanafi Jurisprudence under Imam AlShaybani as he had studied the jurisprudence of Hijaz under Imam Malik in Madina.

He had also collected books of AlShaybani and others and carried out an analytic study on Iraq jurisprudence.Thus, Shafi became the first jurist who had acquainted with both the fiqh of Hijaz and the fiqh of Iraq. ${ }^{[6]}$ However, Shafi felt uncomfortable with constant confrontation with Hanafi Jurists and decided to leave Bagdad in $188 \mathrm{AH}$.

\section{Dispute with Malik and Iraqi Jurists}

Imam Shafi was warmly welcomed in Makkah. His lectures at Sacred Masjid attracted a huge number of learners from many parts of the world. The unique aspect of his teaching at that stage laid on critical examination of judicial opinions of both Schools of Malik and Hanafi. ${ }^{[7]}$ For such examination he had established a set of principles and scientific guidelines which are called later on as Usool Al-Fiqh - Principles and Methodology to derive Law from textual sources of Shariah. Thus, Imam Shafi differed from his master Imam Malik in most of the judicial point of views. He published a book named "Conflict with Malik". Similarly he also published another book named "Conflict with Jurists of Iraq". ${ }^{[8]}$

\section{Usool Al Fiqh-The Principles of Jurisprudence}

With his high language skill and excellent knowledge in the field of prophetic tradition and comparative jurisprudence, Imam Shafi was in an advantageous position to formulate and introduce a set of principles called Usool Al Fiqh. During his stay in Makkah (188-194) Imam Shafi founded Usool Al-fiqh on one hand and established his own school which differed from the school of Malik and the school of Hanafi on the other. Unlike other Madhabs, Shafi Madhab is firmly based on preset principles of Jurisprudence (Usool Al-fiqh).

\section{Introduction and documentation of Shafi school at Bagdad}

Imam Shafi believed it was the right time to expand what he achieved to the wide range of intellectual circle. He travelled again to Bagdad in 195 at the age of forty five.

In Bagdad the matured personality of Shafi had drawn the attention of every scholar. Intellectuals and higher learners crowded around him. The methodology, the Usool Al-Fiqh that he introduced and the jurisprudence that he imparted were entirely new to the intellectual circle of Bagdad. Famous Jurists like Imam Ahmed Bin Hanbal and Ishaq Bin Rahawaih and others joined him as students. Ishaq Bin Rahawaih said: prior to Imam Shafi's arrival at Bagdad, we never knew what abrogation was and abrogated."

It was during this period that he documented all that he had achieved. He authored two books by dictating them to one of his leading disciples Al Zafarani: one was on Usool Al-Fiqh which was called later on as AlRisala and the other was a collection of his judicial opinions - Fiqh. After a period of two or three years, Imam 
Shafi decided to leave Bagdad. Political changes and increasing influence of Mu'tazila in Bagdad might have made him to get out of Bagdad.

According to authentic sources, he was invited to Egypt by its governor, Abbas Bin Abdullah Musa. Accepting the invitation, Imam Shafi travelled to Makkah in 198 to visit the Holy Ka'ba and see off his teachers and students. On the way from Makkah to Egypt, he paid one Shorter visit to Bagdad and finally arrived at Egypt in 199 and settled there at the age of fifty. ${ }^{[9]}$

\section{Revival of Shafi School in Egypt}

Under patronage of the governor, Imam Shafi comfortably settled in Egypt and devoted all his time to teaching and compiling his works. Imam Shafi's revival of his Madhab in Egypt was the most significant development of that period. He revised and changed most of his judicial opinions that he had issued at Bagdad to the extent that it was called as new school of Shafi.

Before his death in $204 \mathrm{AH}$, His revived books of Al Risala and Al Umm were compiled by Al Rabi as dictated by Imam Shafi.

\section{Old and New Schools:}

All judicial views said or texted by Imam Shafi while he was at Bagdad and compiled by dictating to his disciple AlZafarani were identified as old School. All legal opinions of Imam Shafi after his migration to Egypt, reported by his disciples and documented in his books compiled in Egypt were called as new school of Shafi.

\section{Balancing between Schools of thought:}

Imam Shafi, after he had fully acquainted with knowledge of Hanafi jurisprudence in Bagdad, believed that there was a necessity to restrict free exercise of analogy and give supremacy to the Prophetic Tradition in deriving law. He made a thorough study on books of Imam Al Shaybani marking footnotes and refuting Hanafi opinions one by one. Later on, he compiled a book on the conflict with the Iraqi jurists. ${ }^{[10]}$

Similarly he tried to bring a kind of balance among the followers of Maliki School. When it was told that Imam Malik, his master, was celebrated in Western Provinces of Islamic world to the extent that his cap was regarded among them as sacred, Imam Shafi did not hesitate to prove that his master Malik was a human being who makes mistakes. He enumerated about twenty errors of his master in handling the Prophetic Traditions and compiled a book on the conflict with Malik.

\section{Reason for revival of the School:}

There are many arguments among the scholars on why Imam Shafi revived his Madhab after his migration to Egypt. Changing Fatwa considering the changed environment is one of the basic principles in Shariah. Based on this principle, Imam Shafi might have revived his Madhab at Egypt to be more suitable to the new environment. This argument was put forward by some of the contemporary scholars. However, this argument is refuted on the following facts:

After formulation of his new school at Egypt, Imam Shafi abolished his old school which was authored by him at Bagdad and never allowed people to narrate from his old school. It means that his Ijthihad was not based on changed environment and his Madhab is not confined to a particular country or environment. As a matter of fact Shafi madhab is followed across the world irrespective of the different environments. Replying a question about Imam Shafi's books, Imam Ahmed Bin Hanbal said: "His books of Egypt edition are more perfect, because they were compiled in Iraq and rewritten and perfected in Egypt. Rewriting of Shafi's Books in Egypt can be viewed as normal revision of the books in order to correct errors occurred in previous version and fine tune them.

Further, the revival of Shafi School in Egypt was based on the revised Usool Al-Fiqh, the principles and methodology laid down in Al-Risala. The elaborated discussion in the old Al Risala was confined to Quran and Sunnah, where as the revised Al Risala is comprehensively discussing on Ijma and Qiyas in addition to Quran and Sunnah. Imam Shafi had dictated the new Al Risala to his disciple without referring to the previous version, since it was not available on his hands after he had migrated to Egypt. ${ }^{[11]}$ Thus it is understood that Al Risala was not just revised in Egypt but it was rewritten comprehensively in the matured later period of Imam Shafi's life. Impact of the new Al Risala also was one of the reasons for revival of the Shafi School. 
According to the report of Al Rabi, one of the principle disciples of Shafi, It seems that Imam Shafi wanted to present an alternative of Hanafi and Maliki Schools in Egypt. Before arrival at Egypt, Imam Shafi learned from Al Rabi that the people of Egypt were divided into groups; follower of Maliki School or follower of Hanafi School. At that point as reported by Al Rabi, Imam Shafi said: "They will be engaged with an alternative". ${ }^{[12]}$

\section{Conclusion}

Shafi School of thought emerged in a situation where Iraqi School of thought was seem to be extensively exercising free analogy in deriving law, while Hijazi school was extremely rejecting it. In such a situation, there was no better way for Jurists like Imam Shafi who was well acquainted with both the Schools than to bridge the gap between them, highlighting the week points of two Schools and establish his own School. The Books on "Conflicts with Malik" and "Conflicts with Iraqi Jurists" published by Imam Shafi paved a way for an alternative School. Unlike other Schools, Shafi School was based on the preset scientific principles and methodology.

Revival of the Shafi School in Egypt was mainly an impact of revision carried out in his book Al Risala. The matured legal reasoning talent that was attained by Imam Shafi in the later period of his age was also viewed as one the natural factors of revival of his juristic opinions. However, the argument of environmental factor and its influence on revival of Shafi School is refuted.

\section{Reference}

[1] Ibn Kathir, Manaqib al Imam al Shafi, Riyadh, KSA: 1992, pp 67

[2] Hafiz Ibn Hajar, Tawaalee al Ta'sees li Maali Muhammad Idrees, Beirut, Palestine: Dar al Kutub al Ilmiyyah, 1986, pp 51.

[3] Imam Nawawi, Tahdeeb al Asma wa al Lughaat, Beirut, Palestine: Idhara al Tibaah al Muneeriyyah, Vol. 1, pp 51.

[4] Ibn Kathir, Manaqib al Imam al Shafi, Riyadh, KSA: 1992, pp 72-73.

[5] Al Razi, Manaqib Al Imam Al Shafi, Cairo, Egypt: Maktabah Kulliyat Azharia, 1986, pp 10

[6] Hafiz Ibn Hajar, Tawaalee al Ta'sees li Maali Muhammad Idrees, Beirut, Palestine: Dar al Kutub al Ilmiyyah, 1986, pp 73.

[7] Abu Zahrah, Imam al Shafi Hayaathuhu wa Asruhu, Cairo, Egypt: Dar al Fikr al Arabi, 2008, pp 126-127.

[8] Abu Zahrah, Tarikh al Madaahib al Islamiyyah, Cairo, Egypt: Dar al Fikr al Arabi, pp 445.

[9] Al Baihaqi, Manaqib al Imam al Shafi, Cairo, Egypt: Maktabah Dar al Turaas, 1970, Vol. 1, pp 239.

[10] Akram Yusuf AlQawasimi, Al Madkhal Ilaa Madhab Al Imam Al Shafi, Jordan: Dar al Nafayis, 2003, pp 236.

[11] Hafiz Ibn Hajar, Tawaalee al Ta'sees li Maali Muhammad Idrees, Beirut, Palestine: Dar al Kutub al Ilmiyyah, 1986, pp 153.

[12] Ibid, pp 152. 